\title{
PENGARUH PENDAPATAN ASLI DAERAH DAN DANA PERIMBANGAN TERHADAP PERTUMBUHAN EKONOMI DAN KEMISKINAN DI PROVINSI NUSA TENGGARA TIMUR
}

\author{
Marianus Manek ${ }^{1}$, Rudy Badrudin ${ }^{2} \bowtie$ \\ ${ }^{1}$ Sekolah Tinggi Ilmu Sosial dan Ilmu Politik Fajar Timur Atambua \\ e-mail: manek_marianus@yahoo.co.id \\ ${ }^{2}$ Sekolah Tinggi Ilmu Ekonomi YKPN Yogyakarta \\ e-mail: rudybadrudin.stieykpn@gmail.com
}

\begin{abstract}
This study aims to analyze the influence of local revenue and equalization fund on the economic growth and the poverty of regencies/cities in the East Nusa Tenggara Province. Sample in this study consists of 21 regencies/cities in the East Nusa Tenggara Province. The type of data used in this study is secondary data, time series and cross-sectional data of regencies/cities since 2007 to 2016. Data are examined by using SEM-based variant named WarpPLS. The results of this study indicate that the local revenue had significant positive effect on economic growth, local revenue had significant negative effect on poverty, equalization fund had no significant negative effect on economic growth and poverty, and economic growth had no significant negative effect on poverty.
\end{abstract}

Keywords: local revenue, equalization fund, growth, poverty

\begin{abstract}
Abstrak
Penelitian ini bertujuan untuk menganalisis pengaruh pendapatan asli daerah dan dana perimbangan terhadap pertumbuhan ekonomi dan kemiskinan kabupaten/kota di Provinsi Nusa Tenggara Timur. Sampel dalam penelitian ini terdiri atas 21 kabupaten/kota di Provinsi Nusa Tenggara Timur. Jenis data yang digunakan dalam penelitian ini adalah data sekunder, runtut waktu dan data cross-sectional kabupaten/kota sejak tahun 2007 sampai dengan 2016. Data diolah dengan menggunakan varian berbasis SEM yang disebut WarpPLS. Hasil penelitian ini menunjukkan bahwa pendapatan asli daerah memiliki dampak positif yang signifikan terhadap pertumbuhan ekonomi, pendapatan asli daerah memiliki dampak negatif yang signifikan terhadap kemiskinan, dana perimbangan tidak memiliki dampak negatif yang signifikan terhadap pertumbuhan ekonomi dan kemiskinan, dan pertumbuhan ekonomi tidak memiliki dampak negatif yang signifikan terhadap kemiskinan.
\end{abstract}

Kata kunci: pendapatan asli daerah, dana perimbangan, pertumbuhan, kemiskinan 


\section{PENDAHULUAN}

Pembangunan daerah merupakan suatu proses dimana pemerintah daerah dan masyarakatnya mengelola sumber-sumber daya yang ada serta membentuk suatu pola kemitraan antara pemerintah daerah dengan sektor swasta untuk menciptakan lapangan pekerjaan baru selain merangsang perkembangan kegiatan ekonomi dalam wilayah tersebut (Arsyad, 2010: 298). Dalam pelaksanaannya, pembangunan daerah di Indonesia mengalami hambatan karena otonomi daerah belum optimal dijalankan (Badrudin, 2011). Oleh karena itu untuk mengatasi hambatan tersebut, pemerintah menetapkan otonomi daerah yang mulai diberlakukan pada tahun 2001 berdasar Undang-Undang No. 22/1999 tentang Pemerintahan Daerah dan Undang-Undang No. 25/1999 tentang Perimbangan Keuangan antara Pemerintah Pusat dan Pemerintahan Daerah yang kemudian digati dengan Undang-Undang No. 23/2014 tentang Pemerintahan Daerah dan Undang-Undang No. 33/2004 tentang Perimbangan Keuangan antara Pemerintah Pusat dan Pemerintahan Daerah. Salah satu tujuan otonomi daerah adalah untuk menjadikan pemerintah lebih dekat dengan masyakatnya, sehingga layanan pemerintah dapat dilakukan dengan lebih efisien dan efektif dan dapat meningkatkan kesejahteraan dan layanan masyarakat.

Hal ini berdasarkan asumsi bahwa pemerintah daerahmemiliki pemahaman yang lebih baik mengenai kebutuhan dan aspirasi masyarakatnya daripada pemerintah pusat. Berdasar otonomi daerah, pemerintah daerah dapat menyelesaikan permasalahannya dalam mengelola daerahnya, sehingga mampu mengelola sumberdayanya secara mandiri demi tercapainya tujuan pembangunan daerah serta pemerataan dan pemiliharaan hubungan yang serasi antara pemerintah pusat dan daerah (Badrudin, 2015). Salah satu bentuk dari pelaksanaan otonomi daerah adalah adanya desentralisasi fiskal, yaitu pemberian sumber-sumber penerimaan bagi daerah yang dapat digali dan digunakan sendiri sesuai dengan potensinya masingmasing. Secara teoritis, pengukuran kemandirian daerah diukur dari Pendapatan Asli Daerah (PAD). Sumber PAD berasal dari pajak daerah, hasil retribusi daerah, hasil perusahaan milik daerah serta hasil pengolahan kekayaan daerah lainnya yang dipisahkan, dan lain-lain pendapatan daerah yang sah (Taryono dan Ekwarso, 2012).

Dengan adanya desentralisasi fiskal, daerah mempunyai kewenangan yang lebih besar untuk mengoptimalkan PAD-nya, sehingga porsi PAD sebagai komponen penerimaan daerah juga meningkat. Peningkatan PAD yang dianggap sebagai modal, secara akumulasi akan lebih banyak menimbulkan eksternalitas yang bersifat positif dan dapat mempercepat pertumbuhan ekonomi. Desentralisasi fiskal di satu sisi memberikan kewenangan yang lebih besar dalam pengelolaan daerah, tetapi di sisi lain memunculkan persoalan baru. Setiap daerah mempunyai kemampuan yang tidak sama dalam mendanai kegiatan operasional didaerahnya masing-masing, sehingga menimbulkan ketimpangan fiskal antardaerah (Haryanto dan Adi, 2007). Sumber pembiayaan yang utama dari penyelenggaraan pemerintahan dan pembangunan daerah, baik provinsi, kabupaten dan kota mestinya berasal dari kemandirian daerah yang bersumber dari Pendapatan Asli Daerah (PAD). Dalam realisasinya, Kuncoro (2004) menemukan bahwa PAD hanya mampu membiayai belanja pemerintah daerah paling tinggi sebesar 20\%. Untuk mengatasi ketimpangan tersebut, pemerintah pusat mentransfer Dana Perimbangan untuk masing-masing daerah yang terdiri dari Dana Bagi Hasil (DBH), Dana Alokasi Umum (DAU), dan Dana Alokasi Khusus (DAK). 
Berdasar Undang-Undang No. 33/2004 tentang Perimbangan Keuangan antara Pemerintah Pusat dan Pemerintahan Daerah sebagai pengganti Undang-Undang No. 25/1999 tentang Perimbangan Keuangan antara Pemerintah Pusat dan Pemerintahan Daerah, Dana Bagi Hasil (DBH) adalah dana yang bersumber dari pendapatan APBN yang dialokasikan kepada daerah berdasarkan angka persentase untuk mendanai kebutuhan daerah dalam rangka pelaksanaan desentralisasi. DBH dilakukan berdasarkan prinsip by origin (daerah penghasil) dan penyaluran berdasarkan realisasi penerimaan. Dana Alokasi Umum (DAU) merupakan dana yang berasal dari pemerintah pusat (APBN) yang dialokasikan dengan tujuan pemerataan keuangan antardaerah untuk membiayai kebutuhan pengeluaran pemerintah daerah dalam rangka pelaksanaan desentralisasi. Dengan DAU pemerintah daerah dapat menggunakan untuk memberi layanan yang lebih baik kepada publik. Dana Alokasi Khusus (DAK) merupakan dana yang bersumber dari APBN yang dialokasikan kepada daerah tertentu dengan tujuan untuk membantu mendanai kegiatan khusus sebagai urusan daerah dan sesuai dengan prioritas nasional. Pemanfaatan DAK diarahkan pada kegiatan investasi pembangunan, pengadaan, peningkatan, dan perbaikan sarana dan prasarana fisik dengan umur ekonomis yang panjang, termasuk pengadaan sarana fisik penunjang, dan tidak termasuk penyertaan modal. Dengan DAK, pemerintah daerah dapat mengoptimalkan belanja modal, karena DAK cenderung akan menambah aset tetap yang dimiliki pemerintah guna meningkatkan pelayanan public (Badrudin, 2016).

Berdasar Undang-Undang No. 23/2014 tentang Pemerintahan Daerah dan Undang-Undang No. 33/2004 tentang Perimbangan Keuangan antara Pemerintah Pusat dan Pemerintahan Daerah, maka terjadi perubahan mendasar mengenai pengaturan hubungan antara pemerintah pusat dan daerah, khususnya dalam bidang administrasi pemerintahan maupun dalam hubungan keuangan antara pemerintah pusat dan daerah (otonomi daerah) (Wayan, 2014). Melalui otonomi daerah, pemerintah daerah dituntut untuk lebih mandiri dalam mengelola keuangan sesuai dengan porsi Pendapatan Asli Daerahnya (PAD) masing-masing daerah serta lain-lain PAD yang sah serta Dana Transfer dari pemerintah pusat yang dapat digunakan secara efektif dan efisien oleh pemerintah daerah dalam meningkatkan layanan kepada masyarakat.

Di samping itu, otonomi daerah bertujuan untuk mendorong pertumbuhan ekonomi, melalui belanja pembangunan dan investasi swasta. Kontribusi belanja pembangunan akan menarik investor untuk berinvestasi di daerah sehingga akan memperluas basis kegiatan ekonomi di berbagai sektor, dan secara khusus akan memperluas lapangan usaha dan menurunkan tingkat pengangguran dan kemiskinan. Ciri utama suatu daerah otonom mampu berotonomi terletak pada kemampuan daerah untuk mengelola rumah tangganya sendiri dengan mengandalkan kemampuan keuangan daerahnya sendiri (Badrudin dan Baldric, 2015). Berkaitan dengan hal itu, strategi alokasi belanja daerah berperan penting dalam meningkatkan penerimaan daerah. Semakin banyak pendapatan yang dihasilkan oleh daerah, baik dari Dana Perimbangan maupun Pendapatan Asli Daerah maka daerah akan semakin mampu melaksanakan pembangunan di daerahnya masing masing. Berdasar penjelasan tersebut, maka penelitian ini bertujuan untuk menguji dan menganalisis pengaruh Pendapatan Asli Daerah terhadap pertumbuhan ekonomi dan kemiskinan; pengaruh Dana Perimbangan terhadap pertumbuhan ekonomi dan kemiskinan; dan pengaruh pertumbuhan ekonomi terhadap kemiskinan di kabupaten/kota Provinsi Nusa Tenggara Timur. 


\section{TINJAUAN PUSTAKA}

\section{Desentralisasi Fiskal}

Desentralisasi merupakan instrumen untuk memberikan layanan publik yang lebih baik dan menciptakan suatu proses pengambilan keputusan publik yang demokratis. Dalam desentralisasi, akan diwujudkan pelimpahan wewenang kepada tingkat pemerintahan yang lebih rendah untuk melakukan pembelanjaan, wewenang untuk memungut pajak, terbentuknya dewan yang dipilih oleh rakyat, kepala daerah yang dipilih oleh rakyat, dan adanya bantuan dalam bentuk transfer dari pemerintah pusat.

Desentralisasi fiskal merupakan penyerahan kewenangan fiskal dari pemerintah pusat kepada pemerintahan daerah. Menurut Widjayanto (2013), manfaat desentralisasi fiskal adalah efisiensi dan ekonomis. Anggaran daerah untuk layanan publik dapat lebih mudah disesuaikan dengan preferensi masyarakat setempat dengan tingkat akuntabilitas dan kemauan bayar yang tinggi. Desentralisasi fiskal juga bermanfaat untuk meningkatkan penerimaan pajak daerah.

Pelaksanaan desentralisasi fiskal di Indonesia mengacu kepada Undang-Undang No. 33/ 2004 tentang Perimbangan Keuangan antara Pemerintah Pusat dan Pemerintahan Daerah. Menurut undang-undang tersebut desentralisasi fiskal adalah penyerahan wewenang pemerintahan oleh pemerintah pusat kepada daerah otonom untuk mengatur dan mengurus urusan pemerintahan dalam sistem Negara Kesatuan Republik Indonesia. Melalui undang-undang tersebut pemerintah pusat melimpahkan wewenang kepada pemerintahan daerah untuk menggali pendapatan dan melakukan fungsi alokasi secara mandiri dalam merencanakan dan menetapkan prioritas pembangunan.

\section{Pendapatan Asli Daerah}

Menurut Situngkir (2009), PAD merupakan penerimaan daerah yang berasal dari sumber ekonomi asli daerah. Pasal 157 Undang-Undang No. 32/2004 tentang Pemerintahan Daerah dan Pasal 6 UndangUndang No. 33/2004 tentang Perimbangan Keuangan antara Pemerintah Pusat dan Pemerintahan Daerah menjelaskan bahwa sumber PAD terdiri Pajak Daerah, Retribusi Daerah, hasil pengelolaan kekayaan daerah yang dipisahkan, dan Lain-lain PAD yang sah. Menurut Pasal 1 Undang-Undang No. 33/2004 tentang Perimbangan Keuangan antara Pemerintah Pusat dan Pemerintahan Daerah, PAD adalah penerimaan yang diperoleh daerah dari sumber-sumber di dalam daerahnya sendiri yang dipungut berdasarkan peraturan daerah sesuai dengan peraturan perundang-undangan yang berlaku. Pendapatan Asli Daerah merupakan sumber penerimaan daerah yang asli digali di daerah yang digunakan untuk modal dasar pemerintah daerah dalam membiayai pembangunan dan usaha-usaha daerah untuk memperkecil ketergantungan dana dari pemerintah pusat.

Berdasar Undang-Undang No. 28/2009 tentang Pajak Daerah dan Retribusi Daerah dijelaskan pengertian tentang pajak daerah dan retribusi daerah. Pajak Daerah sebagai bagian dari PAD adalah kontribusi wajib kepada daerah yang terutang oleh orang pribadi atau badan yang bersifat memaksa berdasarkan undang-undang, dengan tidak mendapatkan imbalan secara langsung dan digunakan untuk keperluan daerah bagi sebesar-besarnya kemakmuran rakyat. Retribusi Daerah sebagai bagian dari PAD adalah pungutan daerah sebagai pembayaran atas jasa atau pemberian izin tertentu yang khusus disediakan dan/atau diberikan oleh pemerintah daerah untuk kepentingan orang pribadi atau badan. Badan adalah sekumpulan orang dan/atau modal yang merupakan kesatuan, baik yang melakukan usaha maupun yang tidak melakukan usaha yang meliputi perseroan terbatas, perseroan komanditer, perseroan lainnya, badan usaha 
milik negara (BUMN), atau badan usaha milik daerah (BUMD) dengan nama dan dalam bentuk apa pun, firma, kongsi, koperasi, dana pensiun, persekutuan, perkumpulan, yayasan, organisasi massa, organisasi sosial politik, atau organisasi lainnya, lembaga dan bentuk badan lainnya termasuk kontrak investasi kolektif dan bentuk usaha tetap.

Dengan perluasan basis pajak dan retribusi yang disertai dengan pemberian kewenangan dalam penetapan tarif tersebut, jenis pajak yang dapat dipungut oleh daerah hanya yang ditetapkan dalam undangundang. Untuk retribusi, dengan peraturan pemerintah masih dibuka peluang untuk dapat menambah jenis retribusi selain yang telah ditetapkan dalam undang-undang sepanjang memenuhi kriteria yang juga ditetapkan dalam undang-undang ini. Adanya peluang untuk menambah jenis retribusi dengan peraturan pemerintah juga dimaksudkan untuk mengantisipasi penyerahan fungsi layanan dan perizinan dari pemerintah pusat kepada daerah yang juga diatur dengan peraturan pemerintah. Selanjutnya, untuk meningkatkan efektivitas pengawasan pungutan daerah, mekanisme pengawasan diubah dari represif menjadi preventif. Setiap peraturan daerah tentang pajak dan retribusi sebelum dilaksanakan harus mendapat persetujuan terlebih dahulu dari pemerintah pusat. Selain itu, terhadap daerah yang menetapkan kebijakan di bidang pajak daerah dan retribusi daerah yang melanggar ketentuan peraturan perundang-undangan yang lebih tinggi akan dikenakan sanksi berupa penundaan dan/atau pemotongan dana alokasi umum dan/atau dana bagi hasil atau restitusi. Dengan diberlakukannya UndangUndang No. 28/2009 tentang Pajak Daerah dan Retribusi Daerah, kemampuan daerah untuk membiayai kebutuhan pengeluarannya semakin besar karena daerah dapat dengan mudah menyesuaikan pendapatannya sejalan dengan adanya peningkatan basis pajak daerah dan diskresi dalam penetapan tarif. Di pihak lain, dengan tidak memberikan kewenangan kepada daerah untuk menetapkan jenis pajak dan retribusi baru akan memberikan kepastian bagi masyarakat dan dunia usaha yang pada gilirannya diharapkan dapat meningkatkan kesadaran masyarakat dalam memenuhi kewajiban perpajakannya.

\section{Dana Perimbangan}

Dana Perimbangan merupakan dana yang bersumber dari APBN yang dialokasikan kepada daerah untuk mendanai kebutuhan daerah dalam rangka desentralisasi. Selain untuk membantu daerah dalam mendanai kewenangannya, dana perimbangan juga bertujuan untuk mengurangi ketimpangan sumber pendanaan antara pemerintah pusat dan daerah serta antarpemerintah daerah. Dana perimbangan merupakan sistem transfer dana dari pemerintah yang merupakan satu kesatuan yang utuh. Tujuan pemerintah pusat melakukan transfer dana kepada pemerintah daerah adalah sebagai tindakan nyata untuk mengurangi ketimpangan pembagian pendapatan nasional, baik vertikal maupun horisontal dan untuk meningkatkan efisiensi pengeluaran pemerintah dengan menyerahkan sebagian kewenangan di bidang pengelolaan keuangan negara agar dapat dinikmati oleh rakyat di daerah yang bersangkutan.

Dana Perimbangan terdiri dari DBH, DAU, dan DAK. Dana Bagi Hasil adalah dana yang bersumber dari pendapatan APBN yang dialokasikan kepada daerah berdasarkan angka persentase untuk mendanai kebutuhan daerah dalam rangka pelaksanaan desentralisasi. DBH dilakukan berdasarkan prinsip by origin (daerah penghasil) dan penyaluran berdasarkan realisasi penerimaan. DBH dapat diklasifikasikan berdasarkan sumbernya, yang terdiri dari pajak bumi dan bangunan (PBB), biaya perolehan hak atas tanah dan bangunan (BPHTB), pajak penghasilan $(\mathrm{PPh})$, dan sumber daya alam yang berasal dari kehutanan yaitu iuran izin usaha pemanfaatan hutan (IIUPH), 
serta provisi sumber daya hutan (PSDH), dan dana reboisasi (DR) yang terdiri dari pertambangan umum yang berasal dari iuran tetap dan iuran eksploitasi perikanan yang berasal dari pungutan pengusaha perikanan dan pungutan hasil perikanan.

DAU merupakan salah satu transfer dana pemerintah pusat kepada pemerintah daerah yang bersumber dari pendapatan APBN yang dialokasikan dengan tujuan pemerataan kemampuan keuangan antardaerah untuk mendanai kebutuhan daerah dalam rangka pelaksanaan desentralisasi. DAU bersifat block grant yang berarti penggunaannya diserahkan kepada daerah sesuai dengan prioritas dan kebutuhan daerah untuk peningkatan layanan kepada masyarakat dalam rangka pelaksanaan otonomi daerah. DAU suatu daerah dialokasikan berdasarkan formula yang terdiri atas celah fiskal dan alokasi dasar. Celah fiskal merupakan selisih antara kebutuhan fiskal dan kapasitas fiskal. Kebutuhan fiskal diukur dengan menggunakan variabel jumlah penduduk, luas wilayah, Indeks Kemahalan Konstruksi (IKK), Produk Domestik Regional Bruto (PDRB) per kapita, dan Indeks Pembangunan Manusia (IPM). Kapasitas fiskal diukur berdasarkan PAD dan DBH. Alokasi dasar dihitung berdasarkan jumlah gaji pegawai negeri sipil daerah. Tujuan dan fungsi dana alokasi umum (DAU) untuk pemerataan kemampuan keuangan antardaerah yang dimaksudkan untuk mengurangi ketimpangan kemampuan keuangan antardaerah melalui penerapan formula yang mempertimbangkan kebutuhan dan potensi daerah. DAU memberikan kontribusi terbesar dalam Dana Perimbangan.

DAK merupakan dana yang bersumber dari APBN yang dialokasikan kepada daerah tertentu dengan tujuan untuk membantu mendanai kegiatan khusus sebagai urusan daerah dan sesuai dengan prioritas nasional. Tujuan DAK antara lain untuk membantu daerah-daerah dengan kemampuan keuangan di bawah rata-rata nasional, dalam rangka mendanai kegiatan penyediaan sarana dan prasarana fisik layanan dasar masyarakat yang merupakan urusan daerah dan menunjang percepatan pembangunan sarana dan prasarana di daerah pesisir dan pulaupulau kecil, daerah perbatasan dengan negara lain, daerah tertinggal/terpencil, daerah rawan banjir/longsor, serta termasuk kategori daerah ketahanan pangan dan daerah pariwisata.

\section{Pertumbuhan Ekonomi}

Pembangunan ekonomi merupakan proses yang bersifat multi dimensional yang mencakup berbagai perubahan mendasar atas struktur sosial, sikap-sikap masyarakat, dan institusi-institusi nasional, dan tetap mengejar akselerasi pertumbuhan ekonomi, penanganan ketimpangan pendapatan, serta pengentasan kemiskinan. Jadi pada hakekatnya, pembangunan itu harus mencerminkan perubahan total suatu masyarakat atau penyesuaian sosial secara keseluruhan tanpa mengabaikan keanekaragaman kebutuhan dasar dan keinginan individual maupun kelompok-kelompok sosial di dalamnya untuk bergerak maju menuju suatu kondisi kehidupan yang lebih baik, secara material maupun spiritual. Berdasarkan arti pembangunan ekonomi tersebut, maka terdapat tiga unsur penting yang terdapat dalam pembangunan ekonomi, pembangunan ekonomi menggambarkan suatu proses terjadinya perubahan secara kontinu, pembangunan ekonomi mengindikasikan adanya keberhasilan dalam meningkatkan pendapatan perkapita, dan kenaikan pendapatan perkapita tersebut berlangsung untuk jangka waktu yang panjang.

Menurut Badrudin (2012:117), pembangunan ekonomi merupakan suatu proses perubahan pada tata susunan ekonomi masyarakat secara menyeluruh sebagai suatu proses transformasi yang dalam perjalanan waktu ditandai dengan perubahan pada landasan kegiatan ekonomi maupun pada kerangka susunan ekonomi masyarakat 
yang bersangkutan. Menurut Hamzah (2009), pertumbuhan ekonomi adalah perkembangan kegiatan dalam perekonomian yang menyebabkan barang dan jasa yang diproduksikan dalam masyarakat bertambah dan kemakmuran masyarakat meningkat. Ukuran yang sering di gunakan dalam menghitung pertumbuhan ekonomi adalah Produk Domestik Bruto (PDB). Pertumbuhan ekonomi dapat dijadikan sebagai salah satu indikator keberhasilan pembangunan ekonomi. Pertumbuhan ekonomi daerah diukur dengan menggunakan PDRB (Haryanto dan Adi, 2007). PDRB secara nyata mampu memberikan gambaran mengenai nilai tambah bruto yang dihasilkan unit-unit produksi pada suatu daerah dalam periode tertentu. Perkembangan besaran nilai PDRB merupakan salah satu indikator yang dapat dijadikan ukuran untuk menilai keberhasilan pembangunan suatu daerah. Dengan kata lain, pertumbuhan ekonomi suatu daerah dapat tercermin melalui pertumbuhan nilai PDRB.

Tingkat pertumbuhan ekonomi dihitung dengan cara membandingkan PDRB tahun tertentu dengan tahun sebelumnya berdasarkan ADHK. Secara umum, pertumbuhan ekonomi dapat diartikan sebagai perkembangan kegiatan dalam perekonomian yang menyebabkan barang dan jasa yang diproduksi dalam masyarakat bertambah dan kemakmuran masyarakat meningkat. Istilah pertumbuhan ekonomi menerangkan atau mengukur prestasi dan perkembangan suatu perekonomian. Pertumbuhan ekonomi dapat juga diartikan sebagai kenaikan Gross domestic product (GDP) atau Gross National Product (GNP) tanpa memandang apakah kenaikan itu lebih besar atau lebih kecil dari tingkat pertumbuhan penduduk, atau apakah perubahan struktur ekonomi terjadi atau tidak (Arsyad, 2010:11-12). Berdasar beberapa definisi tersebut maka dapat disimpulkan bahwa pertumbuhan ekonomi merupakan kemampuan suatu negara atau daerah dalam menyediakan kebutuhan akan barang dan jasa kepada masyarakat dalam jumlah yang banyak sehingga memungkinkan peningkatan standar hidup dan penurunan tingkat pengangguran dalam jangka panjang yang nantinya akan berdampak pada penurunan kemiskinan

\section{Kemiskinan}

Kemiskinanumumnyamenggambarkan rendahnya pendapatan untuk memenuhi kebutuhan pokok. Pengukuran kemiskinan di Indonesia menggunakan kriteria BPS. BPS menentukan kriteria kemiskinan menggunakan pendekatan kebutuhan dasar (basic needs). Berdasarkan pendekatan kebutuhan dasar, ada 3 indikator kemiskinan yang digunakan, yaitu (1) Headcount Index, (2) indeks kedalaman kemiskinan (Poverty Gap Index). (3) indeks keparahan kemiskinan (Poverty Severity Index). Headcount Index digunakan untuk mengukur kebutuhan absolut yang terdiri dari dua komponen yaitu garis kemiskinan makanan (food line) dan garis kemiskinan non makanan (non food line). Garis kemiskinan BPS sebagai dasar untuk perhitungan Headcount index ditentukan berdasarkan batas pengeluaran minimum untuk konsumsi makanan setara dengan 2.100 kalori per hari dan konsumsi non makanan.

Kemiskinan tidak hanya berkenaan dengan tingkat pendapatan tetapi juga dari aspek sosial, lingkungan bahkan keberdayaan dan tingkat partisipasi, kemiskinan jangan dianggap hanya sebagai pendapatan rendah, tetapi harus dianggap sebagai ketidakmampuan kapabilitas. Kemiskinan di daerah pedesaan adalah masalah ketidakberdayaan, keterisolasian, kerentanan dan kelemahan fisik, dimana satu sama lain saling terkait dan mempengaruhi. Namun demikian, kemiskinan merupakan faktor penentu yang memiliki pengaruh paling kuat dari pada yang lainnya.

Berdasar pemahaman tersebut, maka kemiskinan dapat menjadi penentu dan faktor dominan yang mempengaruhi persoalan 
kemanusiaan seperti keterbelakangan, kebodohan, ketelantaran, kriminalitas, kekerasan, perdagangan manusia, buta huruf, putus sekolah, anak jalanan, pekerja anak. Dengan demikian, kemiskinan tidak bisa hanya dipandang dari satu sisi rendahnya pendapatan tetapi harus dari banyak aspek yang saling terkait sehingga bersifat multidimensi. Konsep kemiskinan melibatkan multidefinisi dan alternatif pengukuran. Kemiskinan merupakan satu dari masalah yang sulit untuk didefinisikan dan dijelaskan. Secara umum, kemiskinan dapat diukur dalam dua dimensi yaitu dimensi income atau kekayaan dan dimensi non-faktor keuangan. Kemiskinan dalam dimensi income atau kekayaan tidak hanya diukur dari rendahnya pendapatan yang diterima karena pendapatan rendah biasanya bersifat sementara, tetapi juga diukur melalui kepemilikan harta kekayaan seperti lahan bagi petani kecil dan melalui akses jasa layanan publik. Sedangkan menurut dimensi non-faktor keuangan ditandai dengan adanya keputusasaan atau ketidakberdayaan yang juga dapat menimpa berbagai rumah tangga berpenghasilan rendah.

Sehubungan dengan situasi dan ciri kemiskinan dan agar kemiskinan tidak semakin menguat, maka pemerintah daerah harus meletakkan kemiskinan menjadi salah satu persoalan mendasar yang harus menjadi pusat perhatian untuk cepat ditanggulangi. Pendekatan yang dianggap cukup tepat dalam penanggulangan kemiskinan adalah menciptakan aktivitas ekonomi di daerah yang ditandai dengan kemampuan daerah dalam menciptakan pertumbuhan ekonomi.

\section{Pengembangan Hipotesis}

Peningkatan PAD akan mendorong pertumbuhan ekonomi daerah. Kenaikan PAD akan memicu dan mendorong pertumbuhan ekonomi daerah menjadi lebih baik dari pada sebelumnya. Pada kabupaten/kota di Provinsi Nusa Tenggara Timur, indikator yang dlgunakan untuk mengukur tingkat pertumbuhan ekonomi adalah PDRB. Angka PDRB atas dasar harga konstan yaitu PDRB yang sudah mengeliminasi faktor inflasi dan untuk melihat kenaikan pendapatan yang ril adalah PDRB atas dasar harga konstan. Penelitian Setiyawati (2007) dan Jolianis (2014), membuktikan bahwa PAD berpengaruh positif terhadap pertumbuhan ekonomi, sedangkan DAU berpengaruh negatif terhadap pertumbuhan ekonomi. Penelitian Prakosa (2015), Khoiri (2015), Arini dan Made (2015), serta Putri (2015) membuktikan bahwa PAD berpengaruh positif terhadap anggaran belanja daerah dan pertumbuhan ekonomi. Berdasar penjelasan tersebut, maka disusun hipotesis penelitian sebagai berikut:

H1: Pendapatan Asli Daerah (PAD) berpengaruh signifikan positif terhadap Pertumbuhan Ekonomi di kabupaten/ kota Provinsi Nusa Tenggara Timur.

Pelaksanaan otonomi daerah melalui desentralisasi fiskal adalah pemberian sumber-sumber penerimaan bagi daerah yang dapat digali dan digunakan sendiri sesuai dengan potensinya masing-masing. PAD bersumber dari pajak daerah, hasil retribusi daerah, hasil perusahaan milik daerah, dan hasil pengolahan kekayaan daerah lainnya yang dipisahkan, dan lain-lain pendapatan daerah yang sah. Peningkatan PAD yang dianggap sebagai modal, secara akumulasi akan lebih banyak menimbulkan efek positif dan akan mempercepat pertumbuhan ekonomi. Selanjutnya peningkatan PAD pada akhirnya akan dapat mengurangi pengangguran dan kemiskinan daerah.

Penelitian Hamzah (2009) menjelaskan bahwa PAD dan dana perimbangan secara langsung berpengaruh tidak signifikan terhadap belanja publik, belanja publik secara langsung berpengaruh tidak signifikan terhadap pertumbuhan ekonomi dan secara tidak langsung melalui pertumbuhan 
ekonomi berpengaruh tidak signifikan terhadap kemiskinan dan penggangguran, dan pertumbuhan ekonomi secara langsung berpengaruh signifikan terhadap kemiskinan tetapi berpengaruh tidak signifikan terhadap penggangguran. Penelitian Jolianis (2014), membuktikan bahwa PAD berpengaruh signifikan negatif terhadap kemiskinan. Artinya, semakin besar PAD semakin menurun kemiskinan. Berdasar penjelasan tersebut, maka disusun hipotesis penelitian sebagai berikut:

H2: Pendapatan Asli Daerah berpengaruh signifikan negatif terhadap Kemiskinan di kabupateb/kota Provinsi Nusa Tenggara Timur.

Dana perimbangan untuk masing-masing daerah terdiri dari DBH, DAU, dan DAK. DBH dialokasikan kepada daerah berdasarkan angka persentase untuk mendanai kebutuhan daerah dalam rangka pelaksanaan desentralisasi. DAU dialokasikan dengan tujuan pemerataan keuangan antardaerah untuk membiayai kebutuhan pengeluaran pemerintah daerah dan untuk memberi layanan yang lebih baik kepada publik. DAK dialokasikan kepada daerah tertentu dengan tujuan untuk membantu mendanai kegiatan khusus yang diarahkan padakegiatan investasi pembangunan, pengadaan, peningkatan, dan perbaikan sarana dan prasarana fisik dengan umur ekonomis yang panjang, termasuk pengadaan sarana fisik penunjang.

Penelitian Pujiati (2008) menjelaskan bahwa PAD berpengaruh signifikan positif terhadap pertumbuhan ekonomi, DBH berpengaruh signifikan positif terhadap pertumbuhan ekonomi, DAU berpengaruh signifikan negatif terhadap pertumbuhan ekonomi serta tenaga kerja sebagai faktor utama dalam mempercepat pertumbuhan ekonomi mempunyai pengaruh signifikan positif terhadap pertumbuhan ekonomi.

Penelitian oleh Maryanti dan Endrawati (2010), Jolianis (2014), dan
Anwar et al. (2016) menyimpulkan bahwa DAU berpengaruh signifikan positif terhadap pertumbuhan ekonomi. Setiap DAU yang diterima pemerintah daerah akan ditujukan untuk belanja pemerintah daerah yang salah satunya belanja modal. Hal ini tidak jauh berbeda dengan peran PAD sebagai sumber pendanaan bagi pembangunan sarana dan prasarana infrastruktur yang akan berdampak pada pertumbuhan ekonomi daerah. Berdasar penjelasan tersebut, maka disusun hipotesis penelitian sebagai berikut:

H3: Dana Perimbangan berpengaruh signifikan positif terhadap Pertumbuhan Ekonomi di kabupaten/kota Provinsi Nusa Tenggara Timur.

Penelitian Hamzah (2009) menjelaskan bahwa PAD dan dana perimbangan secara langsung berpengaruh tidak signifikan terhadap belanja publik, belanja publik secara langsung berpengaruh tidak signifikan terhadap pertumbuhan ekonomi dan secara tidak langsung melalui pertumbuhan ekonomi berpengaruh tidak signifikan terhadap kemiskinan dan penggangguran, dan pertumbuhan ekonomi secara langsung berpengaruh signifikan terhadap kemiskinan tetapi berpengaruh tidak signifikan terhadap penggangguran. Penelitian Jolianis (2014), membuktikan bahwa DAU berpengaruh signifikan negatif terhadap kemiskinan. Artinya, semakin besar DAU semakin menurun kemiskinan. Berdasar penjelasan tersebut, maka disusun hipotesis penelitian sebagai berikut:

H4: Dana Perimbangan berpengaruh signifikan negatif terhadap Kemiskinan di kabupaten/kota Provinsi Nusa Tenggara Timur.

Penelitian Setiyawati (2007), membuktikan bahwa PAD berpengaruh positif terhadap pertumbuhan ekonomi, sedangkan DAU berpengaruh negatifterhadap pertumbuhan ekonomi. Pertumbuhan ekonomi berpengaruh negatif terhadap 
kemiskinan dan berpengaruh positif terhadap pengangguran. Penelitian Hamzah (2009) serta Ginting dan Galuh (2013) menjelaskan bahwa pertumbuhan ekonomi berpengaruh signifikan negatif terhadap kemiskinan.

Hubungan antara pertumbuhan ekonomi dan pengurangan kemiskinan diperdalam dengan membedakan pertumbuhan dan kemiskinan ke dalam komposisi sektoral dan lokasi. Hasil studi menunjukkan bahwa pertumbuhan pada sektor jasa di pedesaan menurunkan kemiskinan di semua sektor dan lokasi. Namun pertumbuhan jasa di perkotaan memberikan nilai elastisitas kemiskinan yang tinggi dari semua sektor kecuali pertanian perkotaan. Selain itu pertumbuhan pertanian di perdesaan memberikan dampak yang besar terhadap penurunan kemiskinan di sektor pertanian perdesaan sebagai kontributor terbesar kemiskinan di Indonesia. Hal ini menunjukkan bahwa cara yang paling efektif untuk mempercepat pengurangan kemiskinan adalah dengan menekankan pada pertanian di perdesaan dan jasa di perkotaan. Namun dalam jangka panjang fokus penekanan harus diarahkan pada pencapaian pertumbuhan menyeluruh yang kuat dalam sektor jasa. Berdasar penjelasan tersebut, maka disusun hipotesis penelitian sebagai berikut:

H5: Pertumbuhan Ekonomi berpengaruh signifikan negatif terhadap Kemiskinan di kabupaten/kota Provinsi Nusa Tenggara Timur.

\section{METODE PENELITIAN}

\section{Data dan Sampel Penelitian}

Data yang dipakai dalam penelitian ini adalah data sekunder berupa data time serries dan crossectional antarkabupaten/kota di Provinsi Nusa Tenggara Timur. Sumber data penelitian ini antara lain Badan Pusat Statistik (www.bps.go.id), BPS NTT, dan Direktorat Jenderal Perimbangan Keuangan Kementrian Keuangan Republik Indonesia (www.djpk.depkeu.go.id). Populasi dalam penelitian ini sebanyak 22 kabupatan/kota di Povinsi Nusa Tenggara Timur dengan rentang waktu 2007-2016, namun jumlah sampel yang digunakan hanya 21 kabupaten/ kota. Teknik sampling yang digunakan untuk mendapatkan sampel yang representatif adalah purposive sampling, artinya sebanyak 21 kabupaten/kota di Povinsi Nusa Tenggara Timur dengan rentang waktu 2007-2016 memenuhi kriteria sebagai sampel karena memenuhi persyaratan kelengkapan data yang dibutuhkan dalam penelitian ini.

\section{Variabel dan Pengukuran}

Variabel penelitian yang digunakan dalam penelitian dikelompokan ke dalam dua jenis variabel eskosen dan variabel endogen. Definisi operasional variabel setiap variabel dan ukurannya disajikan pada Tabel 1 berikut ini:

Tabel 1. Definisi Operasional Variabel

\begin{tabular}{lll}
\hline \multicolumn{1}{c}{ Variabel } & \multicolumn{1}{c}{ Bentuk Persamaan/Ukuran } & \multicolumn{1}{c}{ Keterangan } \\
\hline PAD & $\begin{array}{l}\text { Pajak Daerah + Retribusi Daerah + Hasil Pengelolaan } \\
\text { Kekayaan Daerah yang dipisahkan + lain-lain PAD yang sah }\end{array}$ & $\begin{array}{l}\text { Mengukur kemampuan daerah } \\
\text { mengilkan PAD }\end{array}$ \\
DP & DBH+DAU+DAK & $\begin{array}{l}\text { Mengukur total dana perimbangan } \\
\text { PE }\end{array}$ \\
& Pertumbuhan Ekonomi menurut perhitungan BPS & $\begin{array}{l}\text { Laju pertumbuhan ekonomi ber- } \\
\text { dasarkan harga konstan }\end{array}$ \\
K & Persentase Jumlah Penduduk Miskin menurut perhitungan & Rasio Penduduk Miskin \\
\hline
\end{tabular}

\section{Keterangan:}

PAD : Pendapatan Asli Daerah

DP : Dana Perimbagan

Sumber: Data penelitian, 2016.
PE: Pertumbuhan Ekonomi

$\mathrm{K}$ : Kemiskinan 


\section{Model Analisis Data}

Model yang digunakan dalam penelitian yakni analisis SEM berbasis Varians yaitu WarpPLS. Evalusasi model WarpPLS dapat dilakukan dengan pendekatan one step approach, yaitu melakukan evalusasi terhadap struktural model (Inner Model). Proses pengolahan data melalui tahapan merancang model, mengontruksi diagram jalur, melakukan estimasi, mengevaluasi inner model, dan menguji hipotesi. Berdasarkan teori dan studi empiris sebelumnya, maka kerangka konseptual digambarkan dalam Gambar 1 berikut ini:

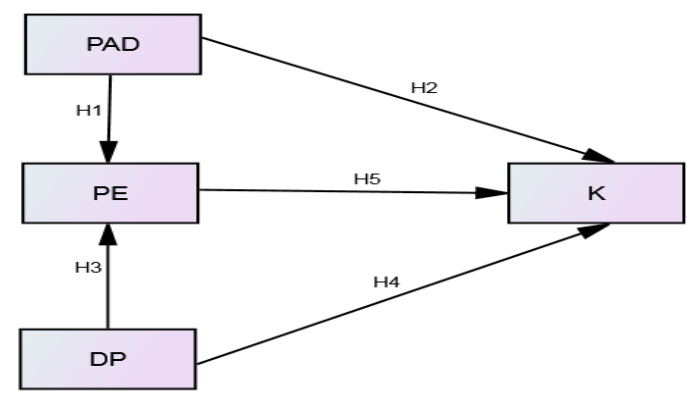

Gambar 1 Diagram Jalur Model Penelitian

Keterangan:

PAD : Pendapatan Asli Daerah

DP : Dana Perimbangan

PE : Pertumbuhan Ekonomi

$\mathrm{K}$ : Kemiskinan

: Observed Variabel

: Pengaruh antarvariabel

\section{HASIL DAN PEMBAHASAN}

\section{Hasil Penelitian}

Analisis deskriptif data penelitian disajikan pada Tabel 2 berikut ini:
Berdasar Tabel 2 tampak rata-rata PAD untuk seluruh kabupaten/kota di Provinsi Nusa Tenggara Timur dari tahun 2007-2016 sebesar Rp50.641.46 juta, dimana PAD terendah terdapat di Kabupaten Sabu Raijua pada tahun 2010 sebesar Rp16.160,81 juta dan PAD tertinggi terdapat di Kota Kupang pada tahun 2016 sebesar Rp111.714,26 juta. PAD menggambarkan kemampuan pemerintah kabupaten/kota di Provinsi Nusa Tenggara Timur dalam menggali semua potensi yang ada untuk meningkatkan pendapatan daerahnya dalam merealisasikan PAD yang direncanakan untuk membiayai kebutuhan daerah pemerintahannya yang didasarkan pada potensi riil daerahnya.

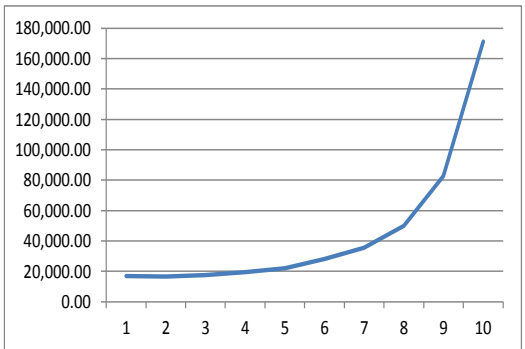

Gambar 2. Perkembangan Nilai PAD di Kabupaten/Kota, Propinsi Nusa Tenggara Timur per tahun, Tahun 2007-2016

Berdasar Gambar 2, nampak perkembangan PAD secara keseluruhan di Provinsi Nusa Tenggara Timur mengalami peningkatan dari tahun ke tahun meskipun terjadi penurunan pada tahun 2008 yaitu Rp15.505,54 juta dibanding tahun 2007 yang mencapai Rp17.067,07 juta. Peningkatan terbesar terjadi pada tahun 2012 yaitu Rp27.672,48juta,dibandingtahunsebelumnya yang hanya mencapai Rp21.406,57 juta. Kuncoro (2004) berpendapat bahwa realitas

Tabel 2. Deskripsi Pendapatan Asli Daerah, Dana Perimbangan, Pertumbuhan Ekonomi, dan Kemiskinan per Kabupaten/Kota di Provinsi Nusa Tenggara Timur, Tahun 2007-2016

\begin{tabular}{ccccc}
\hline Deskripsi & PAD (Rp juta) & DP (Rp juta) & PE (\%) & K (*) \\
\hline Rata-Rata & $50.641,46$ & $508.572,20$ & 5,22 & 22,04 \\
Minimum & $16.160,81$ & $250.737,66$ & 2,98 & 9,57 \\
Maksimum & $111.714,26$ & $849.560,36$ & 10,93 & 32,67 \\
\hline
\end{tabular}

Sumber: Data sekunder, diolah. 
hubungan yang terjadi antara pemerintah pusat dan daerah ditandai dengan tingginya kontrol pusat terhadap proses pembangunan daerah. Hal ini mengindikasikan komposisi peranan mekanisme transfer dari pemerintah pusat melalui dana perimbangan mengalami peningkatan untuk mendanai pelayanan publik. Artinya, daerah yang menerima dana perimbangan lebih besar, menunjukan bahwa PAD yang dihasilkan daerah tersebut terbilang kecil dan memiliki potensi sumber daya yang kurang optimal, sehingga perlu dana penyeimbang dari pemerintah pusat agar dapat menutupi kekurangan dari potensi sumber daya yang dimiliki pada daerah tersebut. Pada waktu pelaksanaan desentralisasi fiskal tahun 2007-2016, penerimaan daerah yang bersumber dari dana perimbangan mengalami peningkatan dari tahun ke tahun walaupun terjadi penurunan pada tahun 2008 dan 2010 (Gambar 3). Ini mengindikasikan bahwa dana perimbangan yang tinggi, menunjukkan ketergantungan daerah terhadap dana perimbangan tinggi dan kemandirian daerah menurun.

Salah satu tujuan instrumen fiskal dari dana perimbangan yaitu berguna untuk mendorong pertumbuhan ekonomi, melalui belanja pembangunan dan investasi swasta. Permbangan Dana Perimbangan di kabupaten/kota Propinsi Nusa Tenggara Timur per tahun selama tahun 2007-2016 nampak pada Gambar 3.

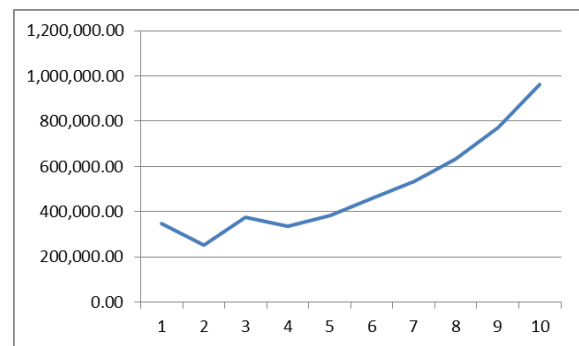

Gambar 3. Perkembangan Nilai Dana Perimbangan di Kabupaten/Kota, Propinsi Nusa Tenggara Timur per tahun, Tahun 2007-2016

Kontribusi belanja pembangunan akan menarik investor untuk dapat berinvestasi di daerah sehinggaakanmemperluas basiskegiatan ekonomi di berbagai sektor, dan secara khusus memperluas lapangan usaha dan menurunkan tingkat pengangguran dan diharapkan dapat menurunkan tingkat kemiskinan. Pertumbuhan ekonomi adalah perkembangan kegiatan dalam perekonomian yang menyebabkan barang dan jasa yang diproduksikan dalam masyarakat bertambah dan kemakmuran masyarakat meningkat. Laju pertumbuhan ekonomi di kabupaten/kota Provinsi Nusa Tenggara Timur yang diukur dengan PDRB harga konstan ratarata untuk seluruh kabupaten/kota di provinsi Nusa Tenggara Timur per 10 tahun sebesar $5,32 \%$ dengan pertumbuhan ekonomi terendah terjadi pada tahun 2009 yaitu hanya mencapai $4,50 \%$ dan pertumbuhan ekonomi tertinggi sebesar 6,39\% pada tahun 2011. Perkembangan laju pertumbuhan ekonomi di kabupaten/kota Propinsi Nusa Tenggara Timur per tahun selama tahun 2007-2016 nampak pada Gambar 4.

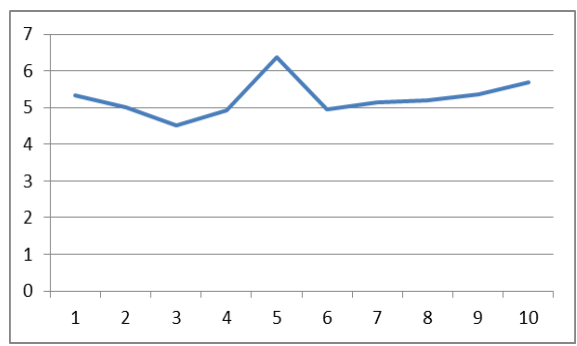

Gambar 4. Perkembangan Laju Pertumbuhan Ekonomi di Kabupaten/Kota, Propinsi Nusa Tenggara Timur per tahun, Tahun 2007-2016

Kemiskinan umumnya dilukiskan sebagai rendahnya pendapatan untuk memenuhi kebutuhan pokok atau kebutuhan dasar (makanan, pakaian, rumah atau tempat berlindung, pendidikan dan kesehatan) sehingga standar hidup layak tidak tercapai. Perkembangan data rasio penduduk miskin di kabupaten/kota Provinsi Nusa Tenggara Timur ditunjukkan pada Gambar 5. Berdasar Gambar 5, nampak rasio penduduk miskin cenderung menurun dari waktu ke waktu. 


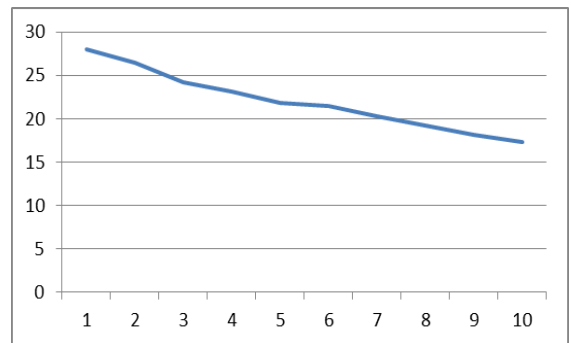

Gambar 5. Perkembangan Rasio Penduduk Miskin di Kabupaten/Kota, Propinsi Nusa Tenggara Timur per tahun, Tahun 2007-2016

Analisis induktif hasil pengujian hipotesis pengujian hipotesis yang dilakukan dengan metode Structural Equation Model - Partial Least Square (SEM-PLS) dengan Warp-PLS diperoleh hasil seperti yang ditunjukkan pada Tabel 3 berikut ini:

\section{Pengaruh Pendapatan Asli Daerah terha- dap Pertumbuhan Ekonomi}

Berdasar hasil pengujian tampak PAD berpengaruh signifikan positif terhadap pertumbuhan ekonomi kabupaten/kota di Provinsi Nusa Tenggara Timur. Hal ini dapat dilihat dari nilai koefisien $(\beta)$ sebesar 0,21 dengan tingkat signifikansi $0,01<0,05$ sehingga disimpulkan bahwa hipotesis pertama (H1) yang menyatakan PAD berpengaruh signifikan positif terhadap pertumbuhan ekonomi kabupaten/kota di Provinsi Nusa Tenggara Timur diterima. Hasil penelitian ini mendukung penelitian
Setiyawati (2007), Jolianis (2014, Prakosa (2015), Khoiri (2015), Arini dan Made (2015), serta Putri (2015) yang menyatakan bahwa PAD berpengaruh positif terhadap pertumbuhan ekonomi, tetapi bertentangan dengan penelitian Hamzah (2009), Tahar dan Maulida (2011), serta Anwar et al. (2016) yang menjelaskan bahwa PAD berpengaruh tidak signifikan terhadap pertumbuhan ekonomi. Pertumbuhan ekonomi yang diproksi dengan PDRB dapat merefleksikan kondisi perekonomian makro suatu daerah sehingga pendapatan masyarakat dan pajak yang dibayar meningkat. Besarnya pajak dan retribusi daerah yang dipungut sangat tergantung pada kondisi perekonomian masyarakat. Semakin baik kondisi perekonomian makro suatu wilayah dapat memberikan kontribusi kepada pemerintah dalam bentuk pajak yang semakin meningkat. Namun perlu diketahui bahwa pajak yang tinggi dapat membebani para wajib pajak sehingga diharapkan pajak dan retribusi daerah tidak terlalu tinggi agar tidak membebani masyarakat. Namun di sisi lain pemerintah mempunyai hak untuk menyediakan fasilitas publik seperti jalan, jembatan, bandar udara dan pelabuhan guna mendorong pertumbuhan perekonomian masyarakat. Sebagai umpan baliknya pemerintah harus memungut pajak sesuai dengan kemampuan masyarakat.

Tabel 3. Hasil Pengujian Hipotesis

\begin{tabular}{cccc}
\hline Hubungan Variabel & Koefisien Jalur & P-value & Hasil Pengujian \\
\hline $\mathrm{PAD} \rightarrow \mathrm{PE}$ & 0,21 & $<0,01$ & Diterima \\
$\mathrm{PAD} \rightarrow \mathrm{K}$ & $-0,43$ & $<0,01$ & Diterima \\
$\mathrm{DP} \rightarrow \mathrm{PE}$ & $-0,01$ & $0,49 *)$ & Ditolak \\
$\mathrm{DP} \rightarrow \mathrm{K}$ & $-0,12$ & $0,14 *)$ & Ditolak \\
$\mathrm{PE} \rightarrow \mathrm{K}$ & $-0,04$ & $0,42 *)$ & Ditolak \\
\hline
\end{tabular}

Keterangan: *) lebih besar daripada 5\%

Sumber: Hasil olah data 


\section{Pengaruh Pendapatan Asli Daerah terha- dap Kemiskinan}

Berdasar hasil pengujian tampak PAD berpengaruh signifikan negatif terhadap kemiskinan kabupaten/kota di Provinsi Nusa Tenggara Timur. Hal ini dapat dilihat dari nilai koefisien $(\beta)$ sebesar -0,43 dengan tingkat signifikansi $0,01<0,05$ sehingga disimpulkan bahwa hipotesis kedua(H2) yang menyatakan PAD perpengaruh signifikan negatif terhadap kemiskinan kabupaten/kota di Provinsi Nusa Tenggara Timur diterima. Hasil penelitian ini mendukung penelitian Hamzah (2009) dan Jolianis (2014) yang menunjukkan bahwa PAD berpengaruh negatif terhadap penurunan kemiskinan baik pengujian secara langsung maupun tidak langsung melalui variabel pertumbuhan ekonomi. Namun hasil penelitian ini bertentangan dengan hasil penelitian Maryanti dan Endrawati (2010) yang menyatakan bahwa PAD berpengaruh positif dan signifikan terhadap kemiskinan.

Salah satu input program penanggulangan kemiskinan adalah jumlah dana yang tersedia. Bagi pemerintah daerah, kemandirian fiskal daerah yang diwujudkan dalam bentuk PAD merupakan salah satu input yang bebas digunakan untuk membiayai program mandiri seperti penanggulangan kemiskinan, memberikan beasiswa pendidikan kepada keluarga yang tidak mampu secara finansial serta menyediakan fasilitas kesehatan di daerah-daerah yang sulit jangkau oleh kendaraan. Apabila pemerintah daerah memiliki kapasitas PAD yang baik, maka kemandirian dalam melaksanakan pembangunan juga akan baik termasuk di dalamnya penanggulangan kemiskinan. Kewajiban masyarakat diwujudkan dalam pembayaran pajak dan retribusi untuk dapat meningkatkan PAD. Oleh karena itu, pemerintah sebagai perencana dan pelaksana pembangunan dapat memberikan umpan balik kepada masyarakat dalam bentuk layanan publik yang memadai dan berkualitas yang didanai dari PAD. Kemampuan keuangan daerah kabupaten/kota di Provinsi Nusa Tenggara Timur apabila dilihat dari ratarata trend pertumbuhan PAD menunjukkan tren yang positif. Kondisi kinerja PAD tersebut berdampak baik terhadap penurunan kemiskinan di daerah. Kinerja PAD tersebut menandakan bahwa secara langsung PAD berperan dalam pengentasan kemiskinan absolut di wilayah Provinsi NTT.

\section{Pengaruh Dana Perimbangan terhadap Pertumbuhan Ekonomi}

Berdasar hasil pengujian SEM WardPLS tampak dana perimbangan berpengaruh signifikan negatif terhadap pertumbuhan ekonomi kabupaten/kota di Provinsi Nusa Tenggara Timur. Hal ini dapat dilihat dari nilai koefisien $(\beta)$ sebesar $-0,01$ dengan tingkat signifikansi $0,49>0,05$ sehingga disimpulkan bahwa hipotesis ketiga (H3) yang menyatakan dana perimbangan berpengaruh signifikan positif terhadap pertumbuhan ekonomi kabupaten/kota di Provinsi Nusa Tenggara Timur ditolak. Hasil penelitian ini mendukung penelitian Pujiati (2008) yang menjelaskan bahwa PAD berpengaruh signifikan positif terhadap pertumbuhan ekonomi, DBH berpengaruh signifikan positif terhadap pertumbuhan ekonomi, DAU berpengaruh signifikan negatif terhadap pertumbuhan ekonomi serta tenaga kerja sebagai faktor utama dalam mempercepat pertumbuhan ekonomi mempunyai pengaruh signifikan positif terhadap pertumbuhan ekonomi.Penelitian ini juga mendukung penelitian Maryanti dan Endrawati (2010), Jolianis (2014), dan Anwar et al. (2016) yang menyimpulkan bahwa DAU berpengaruh signifikan positif terhadap pertumbuhan ekonomi. Namun, penelitian ini bertentangan dengan hasil penelitian Tahar danMaulida (2011) dan Putri (2015) yang menyatakan bahwa DAU berpengaruh tidak signifikan terhadap pertumbuhan ekonomi.

Otonomi daerah membantu menyelesaikan permasalahan perekonomian daerah 
karena pemerintah daerah (provinsi, kabupaten, dan /kota) dapat menyelenggarakan layanan publik dengan biaya rendah. Keyakinan tersebut muncul karena pemerintah daerah lebih dekat dengan masyarakat dan dapat memahami kebtutuhan mereka (masyarakat) serta cara memenuhi kebutuhan tersebut efisien atau dengan biaya yang rendah. Selain itu, pemerintah daerah dapat merespon dengan cepat segala kepentingan di daerah.

\section{Pengaruh Dana Perimbangan terhadap Kemiskinan}

Berdasarkan hasil pengujian hipotesis tampak dana perimbangan berpengaruh tidak signifikan negatif terhadap kemiskinan kabupaten/kota di Provinsi Nusa Tenggara Timur. Hal ini dapat dilihat dari nilai koefisien $(\beta)$ sebesar -0,12 dengan tingkat signifikansi $0,14>0,05$ sehingga disimpulkan bahwa hipotesis keempat (H4) yang menyatakan Dana Perimbangan berpengaruh signifikan negatif terhadap kemiskinan kabupaten/kota di Provinsi Nusa Tenggara Timur ditolak. Artinya, besarnya dana perimbangan yang diterima oleh pemerintah daerah belum optimal dalam memberikan efek terhadap penurunan kemiskinan. Penelitian ini tidak mendukung hasil penelitian Jolianis (2014), yang menyimpulkan bahwa DAU berpengaruh signifikan negatif terhadap kemiskinan. Namun, hasil penelitian ini sejalan dengan penelitian Hamzah (2009) yang menjelaskan bahwa dana perimbangan berpengaruh tidak signifikan terhadap kemiskinan dan penggangguran

Prinsip bahwa kebijakan desentralisasi berpotensi mendorong partisipasi kelompok miskin dalam proses pembangunan agar anggaran di daerah tepat pada sasaran belum berjalan di kabupaten/kota Provinsi Nusa Tenggara Timur. Desentralisasi fiskal yang memaksa pemerintah daerah untuk memperbaiki kualitas layanan publik dasar kepada orang miskin dan memperbaiki efisiensi programnya belum berhasil. Untuk memastikan bahwa desentralisasi mendorong upaya mengurangi kemiskinan, syarat utama yang harus dipenuhi adalah adanya interaksi antara desentralisasi politik, administrasi, dan fiskal dalam menciptakan program yang dapat mengurangi kemiskinan (DJPK, 2012).

Dalam pemberantasan kemiskinan, pemerintah daerah perlu mengadopsi pernyataan tersebut di atas dengan cara memperkuat interaksi antara desentralisasi politik, administrasi, dan fiskal. Dalam hal ini desentralisasi politik dan admisnistrasi didorong untuk membentuk wadah dalam merealisasikan program pemberantasan kemiskinan dan dapat diperkuat dengan perencanaan dan penganggaran yang baik.

\section{Pengaruh Pertumbuhan Ekonomi terha- dap Kemiskinan}

Selama 6 tahun terakhir, tingkat pertumbuhan ekonomi kabupaten/kota di Provinsi Nusa Tenggara Timur mengalami peningkatan secara umum. Namun kondisi perekonomian tersebut berdampak terhadap meningkatnya jumlah penduduk miskin. Hasil penelitian dengan SEM WardPLS menunjukkan bahwa pertumbuhan ekonomi berpengaruh tidak signifikan negatif terhadap kemiskinan kabupaten/kota di Provinsi Nusa Tenggara Timur. Hal ini dapat dilihat dari nilai koefisien $(\beta)$ sebesar -0,04 dengan tingkat signifikansi $0,42>0,05$ sehingga disimpulkan bahwa hipotesis kelima (H5) yang menyatakan bahwa pertumbuhan ekonomi berpengaruh signifikan negatif terhadap kemiskinan kabupaten/kota di Provinsi Nusa Tenggara Timur ditolak. Hasil penelitian ini mendukung penelitian Setiyawati (2007), Hamzah (2009), serta Ginting dan Galuh (2013) yang menjelaskan bahwa pertumbuhan ekonomi berpengaruh signifikan negatif terhadap kemiskinan.

Pertumbuhan ekonomi dan kemiskinan merupakan dua hal yang saling 
mempengaruhi. Pertumbuhan ekonomi yang disertai dengan pemerataan dapat membrantas kemiskinan. Sebaliknya, pertumbuhan ekonomi yang tinggi tidak disertai dengan pemerataan dapat menimbulkan ketimpangan antarwilayah sehingga dapat menciptakan jurang kemiskinan. Di satu sisi, semakin tinggi jumlah penduduk miskin maka akan memperlambat pertumbuhan perekonomian makro suatu wilayah. Kinerja perekonomian daerah apabila dilihat dari laju PDRB selama enam tahun terakhir menunjukkan trend positif. Hal ini sebagai wujud kemajuan pembanguan daerah. Pertumbuhan ekonomi tersebut perlu dipertahankan. Namun pertumbuhan yang positif tersebut belum memberikan dampak yang signifikan terhadap kemiskinan. Berdasar hasil penelitian ini maka pertumbuhan ekonomi yang positif tersebut belum mencerminkan pertumbuhan ekonomi yang inklusif dan padat tenaga kerja. Namun, lebih cenderung pertumbuhan ekonomi yang eksklusif dan padat modal. Kondisi riil menunjukkan bahwa terjadi pertumbuhan ekonomi yang positif namun tingkat kemiskinan relatif tinggi dan menyebar ke seluruh kabupaten dan kota.

Kemiskinan di kabupaten/kota disebabkan oleh berbagai faktor. Oleh karena itu, diperlukan strategi penangulangan yang tepat dan dilakukan secara berkesinambungan sesuai dengan keadaan saat ini. Variabel yang paling umum digunakan untuk menelaah keadaan kemiskinan di suatu wilayah meliputi pendidikan, kesehatan, dan ekonomi. Ketiga variabel tersebut merupakan komponen-komponen yang membentuk Indeks Pembangunan Manusia (IPM) suatu wilayah. Pertumbuhan ekonomi yang tinggi dan berkelanjutan mengindikasikan kemajuan suatu daerah tersebut. Kondisi riil menunjukkan PDRB kabupaten dan kota menunjukkan trend positif selama enam tahun terakhir. Pertumbuhan ekonomi yang positif seharusnya mampu menekan kemiskinan absolut.

\section{SIMPULAN DAN SARAN}

\section{Simpulan}

Berdasarkan hasil analisis dan pembahasan maka disimpulkan bahwa PAD berpengaruh signifikan positif terhadap pertumbuhan ekonomi. Ini bermakna bahwa kenaikan PAD dapat memacu dan memicu pertumbuhan ekonomi dearah menjadi lebih baik daripada pertumbuhan ekonomi daerah pada tahun sebelumnya. PAD berpengaruh signifikan negatif terhadap kemiskinan. Ini bermakna bahwa peningkatan PAD berperan dalam pengentasan kemiskinan absolut di kabupaten/kota Provinsi Nusa Tenggara Timur. Dana Perimbangan berpengaruh tidak signifikan negatif terhadap pertumbuhan ekonomi. Ini bermakna bahwa dana perimbangan belum dialokasikan secara maksimal pada pembangunan infrastruktur untuk mendorong pertumbuhan ekonomi. Dana Perimbangan berpengaruh tidak signifikan negatif terhadap kemiskinan. Ini bermakna bahwa pengelolaan keuangan daerah belum ideal dan penganggaran daerah belum merefleksikan preferensi masyarakat dan kapasitas institusi lokal. Pertumbuhan ekonomi berpengaruh tidak signifikan negatif terhadap kemiskinan. Ini bermakna bahwa pertumbuhan ekonomi yang positif tersebut belum mencerminkan pertumbuhan ekonomi inklusif dan padat tenaga kerja, namun cenderung pertumbuhan ekonomi eksklusif dan padat modal.

\section{Saran}

Berdasar hasil pengujian hipotesis penelitian, terdapat tiga hipotesis yang ditolak. Dua hipotesis penelitian yang ditolak berkaitan dengan pengaruh Dana Perimbangan yang terdiri dari $\mathrm{DBH}$, DAU, dan DAK terhadap pertumbuhan ekonomi dan kemiskinan. Oleh karena DAU merupakan kontributor terbesar Dana Perimbangan, maka peneliti menyarankan kepada pemerintah daerah kabupaten/kota di Propinsi Nusa Tenggara Timur agar mampu 
mengelola Dana Perimbangan, khususnya DAU, sehingga mampu secara langsung maupun tidak langsung melalui peningkatan pertumbuhan ekonomi dapat menurunkan kemiskinan. Inilah yang disebut dengan pembangunan ekonomi inklusif, yaitu pembangunan ekonomi yang tidak hanya mempertimbangkan pertumbuhan ekonomi semata, namun juga memperhatikan capaian penurunan angka pengangguran, kemiskinan, dan indeks Gini sebagai capaian indikator ketimpangan dalam distribusi pendapatan.

\section{REFERENSI}

Anwar, Meilita Lukitasari, Sutomo Wim Palar, dan Jacline I. Sumual. 2016. Pengaruh DAU, DAK, dan PAD terhadap Pertumbuhan Ekonomi dan Kemiskinan (Kota Manado Tahun 2001-2013). Jurnal Berkala Ilmiah Efisiensi. Vol. 16 (2): 218-232.

Arini dan Made Dwi Setyadhi Mustika. 2015. Pengaruh Pendapatan Asli Daerah dan Belanja Tidak Langsung terhadap Kemiskinan Melalui Pertumbuhan Ekonomi di Provinsi Bali tahun 2007-2013. E-Jurnal EP Unud. Vol. 4 (9): 1140-1163.

Arsyad, Lincolin. 2010. Ekonomi Pembangunan. Yogyakarta: Unit Percetakan dan Percetakan STIM YKPN Yogyakarta.

Badrudin, Rudy. 2011. Effect of Fiscal Decentralization on Capital Expenditure, Growth, and Welfare. Economic Journal of Emerging Market. Vol. 3 (3): 211-223.

\section{Ekonomika Otonomi} Daerah. Yogyakarta: UPP STIM YKPN Yogyakarta.

2015. Evaluation of The Specific Allocation Fund for Indonesian Society Welfare. International Journal of Applied Business and Economic Research.
Vol. 13(7): 5607-5624, viewed 29 November 2016, http:// www.serialsjournals.com/serial journalmanager/pdf/1457769178.pdf.

2016. The Model of Inclusive Development in Bali Province. International Journal of Business and Commerce (IJBC). Vol. 6 (1): 09-22, viewed 29 December 2016, http:/www.ijbcnet.com/ 6-1/ IJBC-16-6103.pdf.

Badrudin, Rudy dan Baldric Siregar. 2015. The Evaluation of The Implementation of Regional Autonomy in Indonesia. Economic Journal of Emerging Markets. Vol. 7 (1): 1-11, viewed 19 December 2016, http://journal.uii.ac.id/ index.php/ $\mathrm{JEP} /$ article/view/4257.

Direktorat Jenderal Perimbangan Keuangan. 2012. Grand Design Desentralisasi Fiskal di Indonesia. Jakarta: Kementerian Keuangan Republik Indonesia.

Ginting, Ari Mulianta dan Galuh Prila Dewi. 2013. Pengaruh Pertumbuhan Ekonomi dan Pertumbuhan Sektor Keuangan terhadap Pengurangan Kemiskinan di Indonesia. Jurnal Ekonomi \& Kebijakan Publik. Vol. 4 (2): $117-130$.

Hamzah, Ardi. 2009. Pengaruh Pendapatan Asli Daerah, Dana Perimbangan, dan Belanja Publik terhadap Pertumbuhan Ekonomi, Kemiskinan, dan Pengangguran: Pendekatan Analisis Jalur: Studi Pada 38 Kota/ Kabupaten di Propinsi Jawa Timur Periode 2001-2006. Jurnal Balitbang Depdagri. Vol. 9 (3): 156-176.

Haryanto, David. dan Adi, Priyo Hari. 2007. Hubungan Antara Dana Alokasi Umum, Pendapatan Asli Daerah, BelanjaModal, dan Pendapatan 
Perkapita. Simposium Nasional Akuntansi X, Makasar.

Jolianis. 2014. Analisis Pengaruh PAD, DAU, dan DAK terhadap Kemiskinan pada Kabupaten/Kota di Provinsi Sumatera Barat dengan Pertumbuhan Ekonomi sebagai Variabel Intervening. Economica: Journal of Economic and Economic Education. Vol. 4 (2): 192-209.

Khoiri, Rifki Hasan. 2015. Flypaper Effect dan Belanja Daerah di Provinsi Jawa Barat. Jurnal Signifikan. Vol. 4 (2): 91-106.

Kuncoro, Mudrajat. 2004. Otonomi dan Pembangunan Daerah. Yogyakarta: Unit Percetakan dan percetakan STIM YKPN Yogyakarta.

Maryanti, Ulfi dan Endrawati. 2010. Pengaruh Pendapatan Asli Daerah (PAD), Dana Alokasi Umum (DAU), dan Dana Alokasi Khusus (DAK) Terhadap Pertumbuhan Ekonomi: Studi Kasus Sumatera Barat. Jurnal Akuntansi dan Manajemen. Vol. 21 (3): 145-161.

Prakosa, Kesit Bambang. 2004. Analisis Pengaruh Dana Alokasi Umum (DAU) dan Pendapatan Asli Daerah (PAD) Terhadap Prediksi Belanja Daerah: Studi Empirik di Wilayah Provinsi Jawa Tengah dan DIY. Jurnal Akuntansi Auditing Indonesia. Vol. 8 (2): 111-123.

Putri, Zuwesty Eka. 2015. Analisis Pengaruh Pendapatan Asli Daerah (PAD), Dana Alokasi Umum (DAU), dan Inflasi terhadap Pertumbuhan Ekonomi di Kabupaten/Kota Provinsi Jawa Tengah. Esensi: Jurnal Bisnis dan Manajemen. Vol. 5 (2): 173-186.

Pujiati, Amin. 2008. Analisis Pertumbuhan Ekonomi di Karesidenan Semarang di Era Desentralisasi Fiskal. Jurnal Ekonomi Pembangunan. Kajian
Ekonomi Negara Berkembang. Vol. 11 (1): 61-70.

Setiyawati, Anis dan Hamzah, Ardi. 2007. Analisis Pengaruh PAD, DAU, DAK, dan Belanja Pembangunan terhadap Pertumbuhan Ekonomi, Kemiskinan, dan Pengangguran: Pendekatan Analisis Jalur. Jurnal Akuntansi dan Keuangan Indonesia. Vol. 4 (2): 211-228.

Situngkir, Anggiat. 2009. Pengaruh Pertumbuhan Ekonomi, Pendapatan Asli Daerah, Dana Alokasi Umum, dan Dana Alokasi Khusus Terhadap Anggaran Belanja Modal pada Pemko/Pemkab Sumatera Utara. Tesis. Universitas Sumatera Utara.

Tahar, Afrizal dan Maulida Zakhiya. 2011. Pengaruh Pendapatan Asli Daerah dan Dana Alokasi Umum terhadap Kemandirian Daerah dan Pertumbuhan Ekonomi Daerah. Jurnal Akuntansi dan Investasi. Vol. 12 (1): 88-99.

Taryono dan Ekwarso H. 2012. Analisis Pengeluaran dan Distribusi Pendapatan Penduduk Kabupaten/ Kota di Provinsi Riau Tahun 2008 dan 2009. Jurnal Sosial Ekonomi Pembangunan. Vol. 2 (5): 167-182.

Wayan, Suwendra. 2014. Pengaruh Pendapatan Asli Daerah, Dana Alokasi Umum, dan Dana Alokasi Khusus terhadap Belanja Modal pada Kabupaten Buleleng Tahun 2006 2012. e-Journal Bisma. Vol. 2 (3): 144-157

Widjayanto, Wahyu. 2013. Tinjauan Dampak Kebijakan Desentralisasi Fiskal bagi Kemampuan Keuangan dan Pertumbuhan Ekonomi Daerah. Jakarta: Pusat Pendidikan dan Pelatihan Kekayaan Negara dan Perimbangan Keuangan Badan Pendidikan dan Pelatihan Keuangan. 